The $B D J$ News section accepts items that include general news, latest research and diary events that interest our

readers. Press releases or articles may

be edited, and should include a colour

photograph if possible. Please direct your

correspondence to the News Editor,

Arveen Bajaj at the BDJ, The Macmillan

Building, 4 Crinan Street, London N1 9XW

or by email to bdj@bda.org

\section{New exam for overseas dentists}

The General Dental Council (GDC) is to launch the Overseas Registration Examination (ORE) which replaces the International Qualifying Examination (IQE) in September 2007.

The ORE will be in two parts, with Part One consisting of a written paper covering clinical applied dental science and clinically applied human disease and a written paper in aspects of clinical dentistry, law and ethics, and health and safety.

Part Two will consist of an examination on a dental manikin, an objective structured clinical examination (OSCE) that tests candidates' clinical skills, an examination designed to test candidates' diagnostic and treatment planning skills and a medical emergencies examination.

New candidates applying to sit the ORE must demonstrate that they have at least 1,600 hours clinical experience where they have personally treated patients in the dental chair. This experience can be gained during the undergraduate degree, during post-qualification experience, or a combination of both.

Candidates will have to verify this experience by providing references from University Dental Deans or employers.

Current IQE candidates can transfer across to the new exam and those who have passed Part A of the IQE will be exempt from the first paper in Part One of the new exam. Those who choose not to transfer will be limited to two attempts at each part of the IQE before being automatically transferred to the new exam. The GDC is to open a waiting list for the examination at the end of July.

\title{
Cancer specialist appointed
}

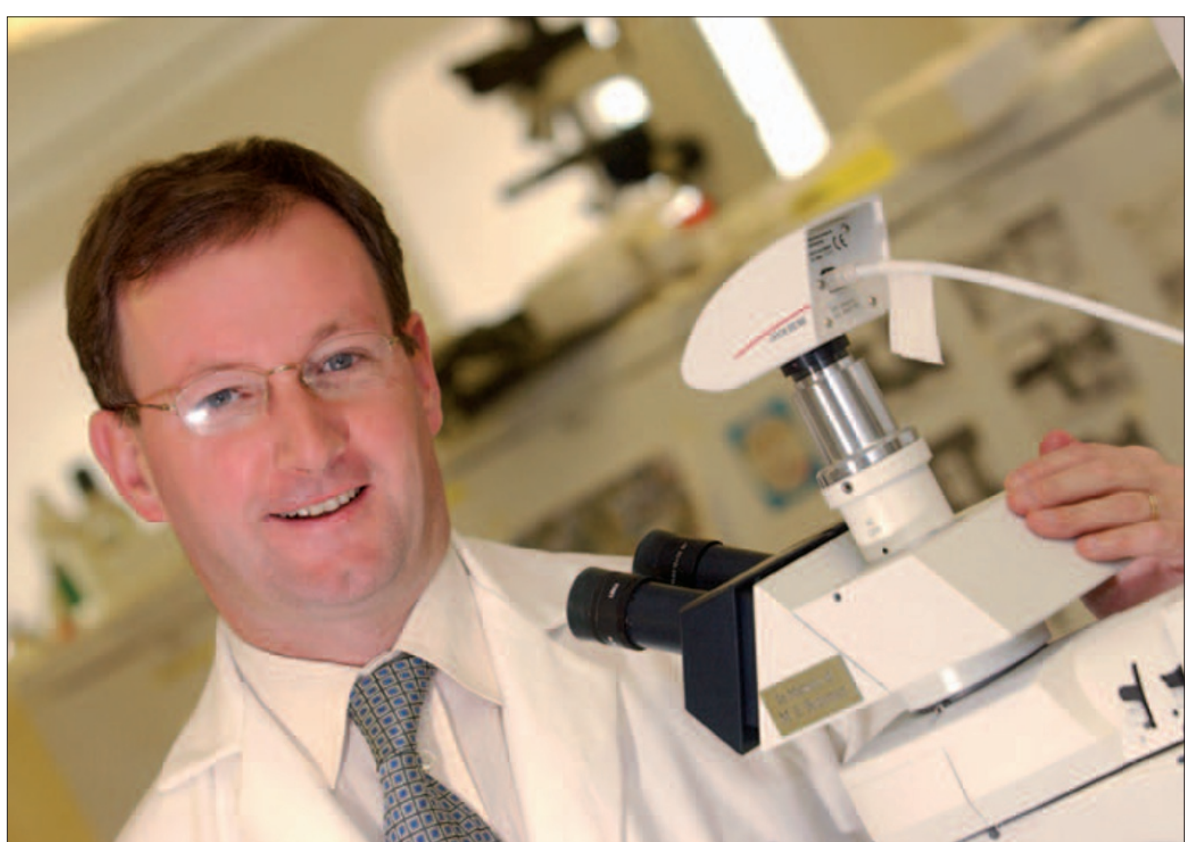

A top cancer research specialist is to lead the development of a new international Medical School at Queen's University, Belfast, Northern Ireland. Professor of Oncology Paddy Johnston, who is Director of the Centre for Cancer Research and Cell Biology at Queen's, is to become Dean of Queen's School of Medicine and Dentistry in September. His mission will be to transform medical education and research in Northern Ireland, bringing together strengths in medicine, dentistry and biomedical sciences at Queen's.

Professor Johnston said, 'Northern Ireland can be a global player in medical research and education, and I believe Queen's will be the catalyst which helps transform its health services. Devolution and the new arrangements for managing the NHS in Northern Ireland have created opportunities to establish new partnerships, allowing Queen's and the five new hospital trusts to respond imaginatively to the 21st century's challenges.'

The University is currently investing more than $€ 45$ million in new buildings and equipment for medicine, dentistry and biomedical sciences.

\section{Dental chain in changeover}

Oasis Healthcare has rejected a previously-agreed $£ 76.9 \mathrm{~m}$ buyout offer from private equity firm Duke Street Capital in favour of a more lucrative deal from Associated Dental Practices (ADP). ADP will pay 91p per ordinary share.

Ron Trenter, Oasis chairman, said: 'We believe that the ADP Offer, which is at a clear premium to the value offered under the Duke Street offer, provides Oasis shareholders with an attractive cash price which reflects the quality of the Oasis business. Accordingly, the Independent Directors of Oasis have withdrawn the recommendation of the Duke Street offer and are now recommending that Oasis shareholders accept the ADP offer.' 


\section{Ugandan schools}

\section{need sponsors}

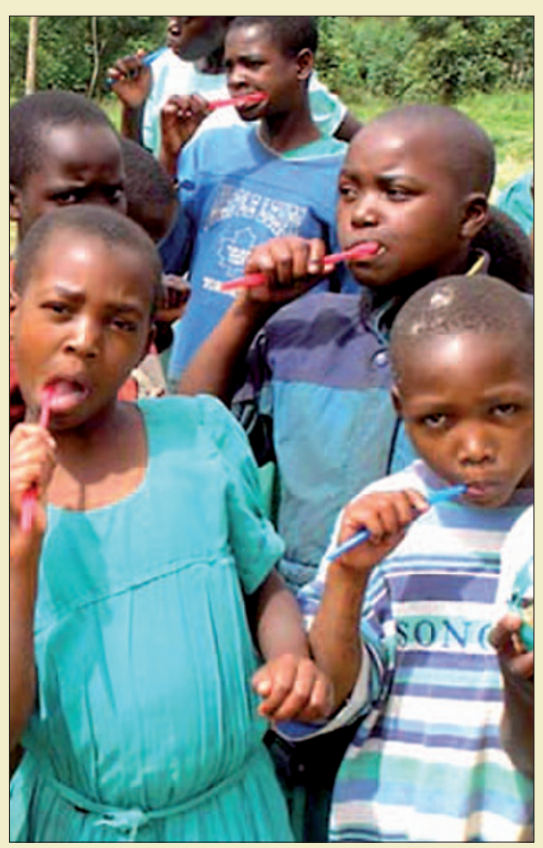

Supervised tooth brushing at Nyamabale School

Oral health charity Dentaid is asking the dental community to sponsor a school oral health programme and help it to continue improving the oral health of thousands of school children in Uganda.

The programme, which has already reached over 5,000 children in six schools in the Kabale region of Uganda, provides the schools with oral screening and on-site treatment of all children by indigenous oral health workers using portable equipment, referring more complicated cases to the Rugurama Health Centre in Kabale. It also provides oral health education using culturally appropriate visual aids supplied by Dentaid and daily toothbrushing with fluoride toothpaste.

Dentaid is now expanding the programme to include a further nine schools in the region and is asking dental practices, laboratories and companies to support the projects and sponsor a whole school for $£ 800$. In return for this generous donation each sponsor will receive a letter from the head teacher of the school, background information on the school and the district, photographs of the school, pictures of the oral health programme being implemented and acknowledgement of their support on the Dentaid website. For more information visit www.dentaid.org, email info@dentaid.org or telephone 01794324249.

\section{Meeting of oral oncology experts}

Over 750 head and neck surgeons, maxillofacial surgeons, otolaryngologists, oncologists and others met in Amsterdam recently for the first congress of the International Academy of Oral Oncology (IA00). Coordinated by the President, Professor Jatin Shah (New York), and the program chairs, Alexander Rapidis (Athens and UCL-Eastman) and Crispian Scully (UCL-Eastman), the congress covered a multitude of topics and included keynote addresses, panel discussions, debates, instructional courses, oral papers and posters.

Pictured from left to right, IA00 officers Professors Langdon (KCL and

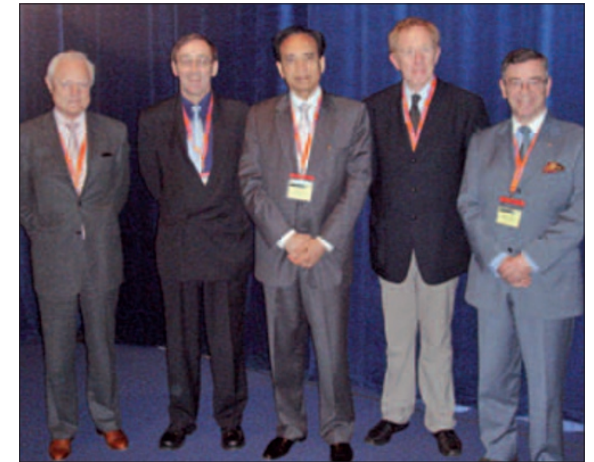

UCL-Eastman), Scully (UCL-Eastman), Shah (New York), Lefebvre (Lille) and Rapidis (Athens and UCL-Eastman).

\section{Innovative design recognised}

The Wrigley's Orbit Complete Oral Healthcare Programme has announced the winner of the 2007 Dental Student Award as Tom Green, final year student studying for a BSc in Oral Health Sciences at Dundee Dental School.

The Wrigley Company's long standing relationship with the British Dental Association (BDA) has provided dental, hygiene and therapist students throughout the UK and the Republic of Ireland with the opportunity to design imaginative and creative material on oral healthcare. This year students were asked to write and develop a resource aimed at patients aged between 18 and 35 to promote a better daily oral healthcare routine.

Tom Green's winning leaflet was chosen because it was seen by the judges to be particularly powerful due to the friendly and informative language used accompanied with strong visuals which outlined the best oral healthcare to maintain a healthy mouth. This routine included brushing twice a day, as well as chewing sugarfree gum like Wrigley's Orbit Complete for 20 minutes after eating during those times where brushing your teeth is not possible.

When asked about the motivation to create his leaflet Tom explained that he thought it was important to use the leaflet to address his patients in the same way that he would in person, providing them with the best advice and care. Tom was presented with his certificate and prize of $£ 1,000$ at this year's BDA conference.

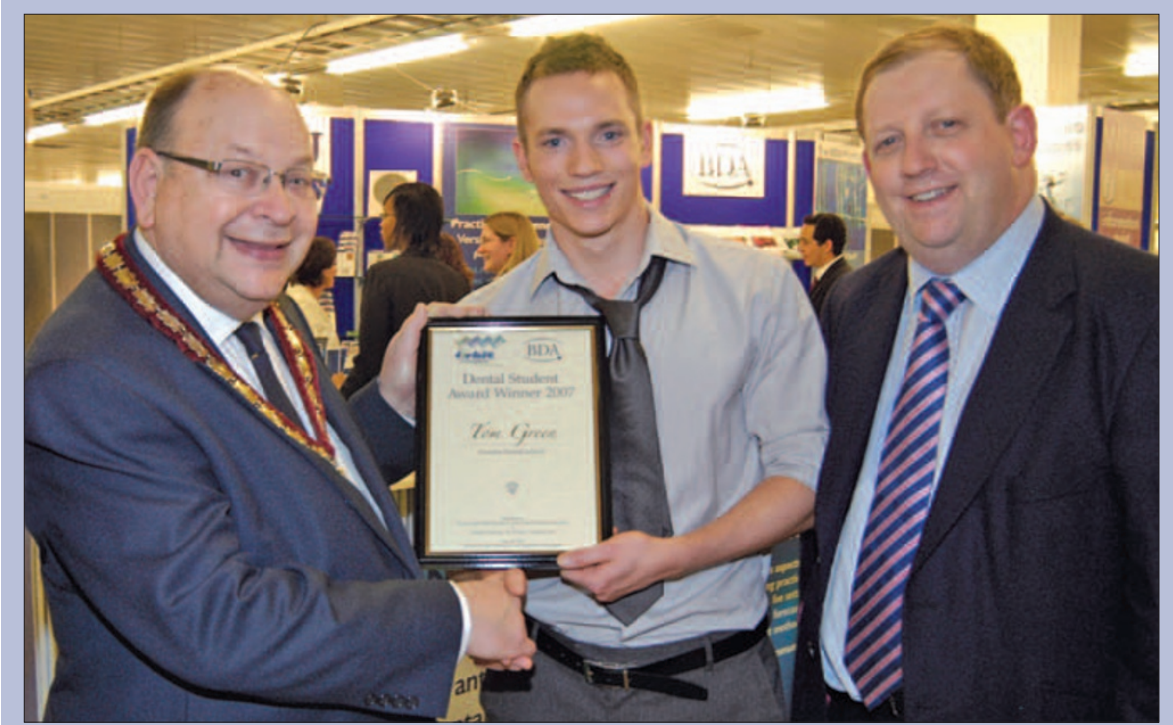

Student Tom Green (centre) was presented the award by Josef L Rich OBE, President of the BDA (left) and Peter Ward, Chief Executive of BDA (right) 


\section{Specialist society installs new President at meeting}

Mr Colwyn Jones, Consultant in Dental Public Health has been installed as President of the British Association for the Study of Community Dentistry (BASCD) at its spring scientific meeting in Edinburgh. BASCD is an independent association of dental public health practitioners and as a specialist society is concerned with dental public health and related subjects.

The meeting was organised by the incoming President with the theme of 'Oral Health inequalities: What matters? What works?' Speakers included Professor Richard Watt on oral health promotion and inequalities, Professor Bill Shaw on developmental anomalies and health inequalities and Professor Mike Lennon on water/salt fluoridation and inequalities.

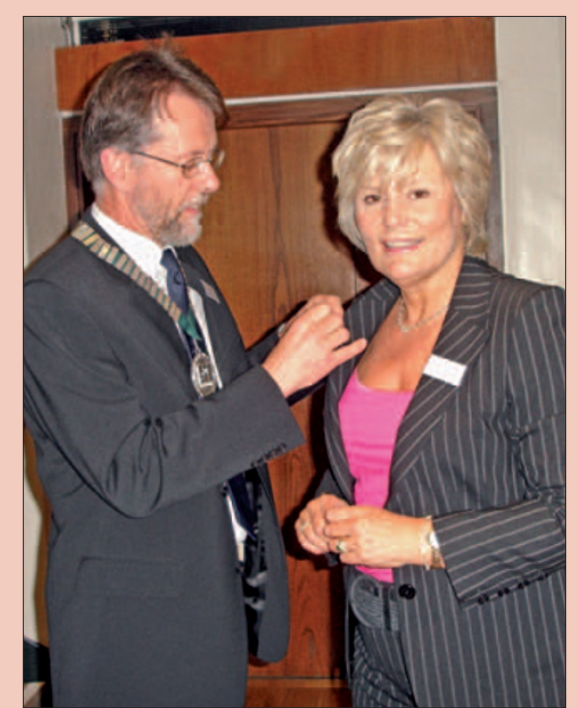

Colwyn Jones, President, presents Sue Gregory with the Immediate Past President's badge

\section{Oral bone loss in postmenopausal women}

Periodontal disease in postmenopausal women is linked to oral bone loss according to a study conducted at the University at Buffalo, New York, USA.

The study involved 1,256 postmenopausal women who were part of a larger population-based investigation, by the National Women's Health Initiative, of risk factors for osteoporosis and oral bone loss in postmenopausal women.

The researchers believe it has provided new information on the prevalence of certain gum-disease-causing oral bacteria in this population and the association of the bacteria with oral bone loss. Results showed that women infected with four bacteria known to cause periodontal disease were more likely to have more severe oral bone loss than those without these oral pathogens.

Two widely recognised periodontal pathogens, Porphyromonas gingivalis and Tannerella forsythensis, were found to infect $15.1 \%$ and $37.9 \%$ of the women, respectively. Two additional oral bacteria suspected to be pathogenic, Prevotella intermedia and Campylobacter rectus, were found in $43.4 \%$ and $17.4 \%$ of women. Senior author on the study Jean Wactawski-Wende said, 'This is one of the first studies in community-dwelling postmenopausal women that assessed bacteria presence and associated it with oral bone loss, while controlling for other factors such as age, smoking status and income.' Results appear in the Journal of Periodontology (2007; 78: 1051-1061).

Blood levels of inflammation markers, which would provide a clear picture of overall risk were not available at the time, but the researchers are now planning to investigate this association.

\section{CPD for dental care professionals}

The General Dental Council (GDC) has announced that all dental care professionals (DCPs) will be required to complete 150 hours of continuing professional development (CPD) every five years, a third of which should be verifiable, from July 2008.

They will be required to complete CPD in the same core subjects as dentists, which are medical emergencies (10 hours per cycle), disinfection and decontamination, and radiography and radiation protection (both 5 hours per cycle). Dental technicians should substitute radiography and radiation protection for materials and equipment ( 5 hours per cycle) as radiography is not within the dental technician curriculum. 


\section{DIARY}

September

4th Annual Meeting of the European Society of Esthetic Dentistry Date: 21-23 September 2007 Venue: Vienna, Austria Email: iris.bobal@media.co.at www.escdonline.eu

148th American Dental Association Annual Session and Marketplace Exhibition Date: 27-30 September 2007 Venue: The Moscone Center, San Francisco, USA

www.ada.org

\section{October}

British Society of Oral Implantology Inaugural Symposium

Date: 6 October 2007

Venue: The University of Glamorgan

Email: support@BSOI.org

www.BSOl.org

\section{Oral Cancer: Challenges}

and Solutions

Date: 6 October 2007

Venue: UCL Eastman Dental Institute, London

www.eastman.ucl.ac.uk

\section{BDTA Dental Showcase}

Date: 18-20 0ctober 2007

Venue: NEC Birmingham

Tel: 01494789959

www.dentalshowcase.com

Annual meeting of the Society of Craniofacial Genetics \& American Society of Human Genetics Meeting Date: 23 October 2007

Venue: Convention Center, San Diego, California, USA

www.craniofacialgenetics.org

\section{FDI Annual World Dental Congress}

Date: 24-27 October 2007

Venue: Dubai, UAE

Email:congress@fdiworldental.org www.fdiworldental.org

\section{Success for Glasgow Dental School staff}

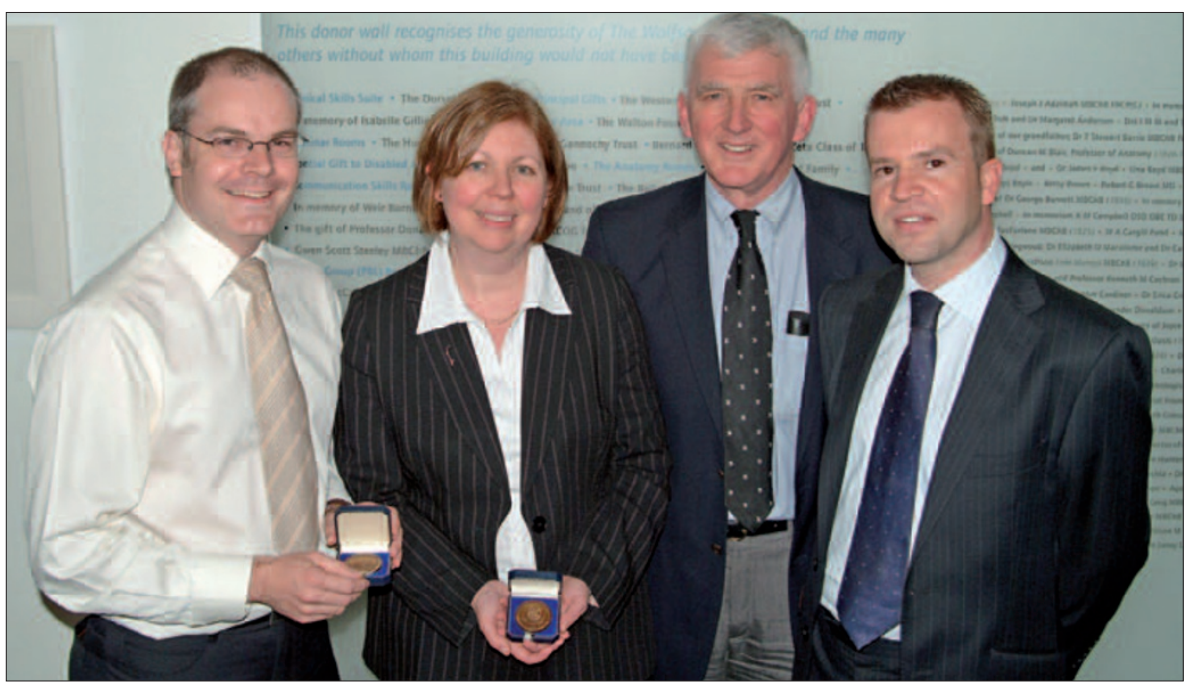

Dr Colin Murray was recently presented with the Bellahouston Medal for the most outstanding thesis $\mathrm{PhD}, \mathrm{MD}$ or DDS) submitted by a medical or dental graduate. Instituted in 1897, it is awarded annually by the University of Glasgow Faculty of Medicine.

In recent years, this award has been won on three occasions by academic staff at Glasgow Dental School: Dr M Petrina Sweeney (2000), Dr Keith Hunter (2005) and Dr Colin Murray. Their theses, in the fields of special care dentistry, oral cancer and oral immu- nology respectively, reflect core themes within the research strategies of the Dental School and Faculty of Medicine and demonstrate the commitment of the Dental School to achieving research excellence.

Pictured just prior to the presentation of Dr Murray's medal at the Wolfson Medical School Building, University of Glasgow are (left to right) Dr Hunter, Dr Sweeney, Professor John Reid (Regius Professor of Medicine \& Therapeutics and Head of the Faculty of Medicine Graduate School) and Dr Murray.

\section{FDI joins global campaign for smoke-free environments}

While England has introduced a new law to make all enclosed public places and workplaces in England smoke-free on July 1st 2007, the global smoke-free campaign continues.

The FDI World Dental Federation has joined more than 250 organisations in the Global Smokefree Partnership's Global Voices Campaign. The campaign aims to garner support from countries and organisations around the world for a strong and effective policy in the protection against second-hand smoke. The campaign was launched on the occasion of the 2007 World No Tobacco Day, which called for smoke-free environments, and also in the lead up to the July 2007 meeting of the Conference of the Parties (COP) of the Framework Convention on Tobacco Control (FCTC).

The COP will meet to consider guidelines on the implementation of
Article 8 of the FCTC, which is to provide protection against second-hand smoke. The purpose of the guidelines is to serve as best practices for countries in the implementation of their smoke-free laws.

By joining the Global Voices Campaign, the FDI agrees to support the principles of the campaign. These include that second-hand smoke is a significant health hazard, that there is no safe level of exposure to secondhand smoke, that legislation without exemptions is needed to protect people from the dangers of second-hand smoke and that effective enforcement, implementation and monitoring provisions are necessary components of effective legislation. For more information about the Global Voices Campaign, please visit www.globalsmokefree partnership.org/globalvoices. 